\title{
Maastricht University graduate surveys 2013
}

Citation for published version (APA):

Allen, J. P., \& Meng, C. M. (2013). Maastricht University graduate surveys 2013. ROA. ROA Fact Sheets No. 004 https://doi.org/10.26481/umarof.2013004

Document status and date:

Published: 01/01/2013

DOI:

10.26481/umarof.2013004

Document Version:

Publisher's PDF, also known as Version of record

\section{Please check the document version of this publication:}

- A submitted manuscript is the version of the article upon submission and before peer-review. There can be important differences between the submitted version and the official published version of record.

People interested in the research are advised to contact the author for the final version of the publication, or visit the DOI to the publisher's website.

- The final author version and the galley proof are versions of the publication after peer review.

- The final published version features the final layout of the paper including the volume, issue and page numbers.

Link to publication

\footnotetext{
General rights rights.

- You may freely distribute the URL identifying the publication in the public portal. please follow below link for the End User Agreement:

www.umlib.nl/taverne-license

Take down policy

If you believe that this document breaches copyright please contact us at:

repository@maastrichtuniversity.nl

providing details and we will investigate your claim.
}

Copyright and moral rights for the publications made accessible in the public portal are retained by the authors and/or other copyright owners and it is a condition of accessing publications that users recognise and abide by the legal requirements associated with these

- Users may download and print one copy of any publication from the public portal for the purpose of private study or research.

- You may not further distribute the material or use it for any profit-making activity or commercial gain

If the publication is distributed under the terms of Article $25 \mathrm{fa}$ of the Dutch Copyright Act, indicated by the "Taverne" license above, 
Tuastricht University in Learning!

Research Centre for Education and the Labour Market | ROA

\section{Maastricht University graduate surveys 2013}

\section{ROA Fact Sheet}

ROA-F-2013/4

Researchcentrum voor Onderwijs en Arbeidsmarkt | ROA Research Centre For Education and the Labour Market / ROA 


\section{Maastricht University graduate surveys 2013}

How well does Maastricht University prepare its students for the labour market? What are the short and medium term career paths of Maastricht University alumni, and how do they look back on their time in Maastricht? This fact sheet presents the most important results of a 2013 survey amongst two cohorts of Maastricht University alumni. The first cohort graduated in the academic year 2006-2007 (six years prior to the survey), and the second in the academic year 200I-2002 (II years prior to the survey). ${ }^{1,2}$

\section{Position in the labour market}

Six to eleven years after graduation, around 95\% of the Maastricht University alumni have paid employment. Of those not currently working, a small percentage are searching for work, which means that overall only around $2 \%$ of graduates in both cohorts reported to be out of the labour force. Important reasons for inactivity include participating in further education or to be taking care of children or relatives. Table I gives a more detailed overview of graduates' unemployment rates - that is, the proportion who are not currently working but who are searching for work - by cohort and faculty. Overall, $3 \%$ of the 2006-2007 cohort and $2 \%$ of the $200 \mathrm{I}-2002$ cohort are unemployed. ${ }^{3}$ It should be noted that a substantial part of this unemployment rate can be regarded as frictional (i.e. just a brief time interval between two jobs). It therefore seems that involuntary unemployment is not an issue in for Maastricht University graduates in general. Minor exceptions to this are Arts and Social Sciences and Law graduates five years after graduation. However, since no such problems appear to exist for the older cohorts from the Law faculty and the high percentage for the younger cohort has not been systematically observed in prior survey years (see Appendix A), the high percentage for this faculty may be a statistical anomaly. All things considered, we can conclude that labour market participation is very high for both cohorts of Maastricht University graduates, and that this usually involves paid employment.

I. For the 2006-2007 cohort, of the 1793 alumni we approached, 31\% participated in the survey. Of the alumni from the $200 \mathrm{I}-2002$ cohort, of the 1423 alumni we approached, $31 \%$ responded.

2. The reader should keep in mind that the mix of studies offered by Maastricht University the respondents graduated from might vary between the two cohorts.

3. The unemployment rate might also vary within faculties. In case of the faculty Health, Medicine and Life Science the unemployment rate of Medical alumni is $\% \%$ for both cohorts, whereas for Health and Life Science alumni the unemployment rate is between $4 \%$ and $5 \%$.
Table 1

Unemployment ${ }^{1}$

\begin{tabular}{lcc}
\hline & $\begin{array}{c}\text { \% unemployed } \\
\text { 2006-2007 }\end{array}$ & 2001-2002 \\
\hline Business and Economics & 0 & 1 \\
Health, Medicine and Life Sciences & 3 & 3 \\
Arts and Social Sciences & 6 & $x$ \\
Psychology and Neuroscience & 0 & 0 \\
Law & 7 & 2 \\
Maastricht University & 3 & 2 \\
\hline
\end{tabular}

$1=$ too little information about the Faculty of Humanities and Sciences $\mathrm{x}=$ too few cases

\section{Job characteristics}

It is important that graduates obtain a good match between their education and the requirements of their job, since this is what mainly determines the extent to which they can use their knowledge and skills. The quality of the education-job match is therefore also positively related to job satisfaction, career opportunities and wages. Table $2 \mathrm{a}$ presents the proportion of Maastricht University graduates who show a good horizontal education-job match, that is, who work in jobs for which their own or a related field of study is required.

\section{Table $2 a$}

Horizontal match

\begin{tabular}{lcccccc}
\hline \multicolumn{5}{c}{ field of studie required in current job in relation to own field (\%) } \\
& $\begin{array}{c}\text { 2006-2007 } \\
\text { own or } \\
\text { completely } \\
\text { related } \\
\text { field }\end{array}$ & $\begin{array}{c}\text { different } \\
\text { field }\end{array}$ & $\begin{array}{c}\text { no } \\
\text { specific } \\
\text { field }\end{array}$ & $\begin{array}{c}\text { own or } \\
\text { related } \\
\text { field }\end{array}$ & $\begin{array}{c}\text { completely } \\
\text { different } \\
\text { field }\end{array}$ & $\begin{array}{c}\text { no } \\
\text { specific } \\
\text { field }\end{array}$ \\
\hline $\begin{array}{l}\text { Business and } \\
\begin{array}{l}\text { Economics } \\
\text { Health, }\end{array}\end{array}$ & 88 & 4 & 8 & 82 & 5 & 14 \\
$\begin{array}{l}\text { Medicine and } \\
\text { Life Sciences }\end{array}$ & 86 & 6 & 8 & 85 & 5 & 10 \\
$\begin{array}{l}\text { Arts and Social } \\
\text { Sciences }\end{array}$ & 52 & 16 & 32 & $x$ & $x$ & $x$ \\
$\begin{array}{l}\text { Psychology and } \\
\text { Neuroscience }\end{array}$ & 77 & 10 & 13 & 68 & 11 & 21 \\
$\begin{array}{l}\text { Law } \\
\text { Maastricht }\end{array}$ & 60 & 18 & 22 & 82 & 7 & 12 \\
University & 79 & 9 & 13 & 81 & 6 & 13 \\
\hline
\end{tabular}

$1=$ too little information about the Faculty of Humanities and Sciences $\mathrm{x}=$ too few cases

With $79 \%$ of alumni from the 2006-2007 cohort, and $81 \%$ of the alumni from the $200 \mathrm{I}-2002$ cohort working in a good horizontal match, we can say that the view is positive on this indicator. It appears however that considerable differences exist between graduates from the various faculties. Graduates from the Faculties of Business and Economics and Health, Medical and Life Sciences have above average figures for both cohorts. However, within the Faculty of Health, Medical and Life Sciences, a strong distinction exists between the study of medicine and the studies of

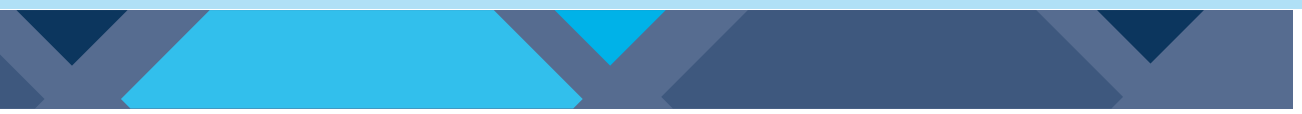


Health and Life sciences. More or less self-evidently given their very specific education, Medical graduates are very well matched (Io०\% for both cohorts), but these figures are clearly lower for the graduates of Health and Life Science studies (2006-2007: 81\%, 200I-2002 77\%). Nonetheless, these percentages are still very close to those for Maastricht University as a whole. Substantially below the university average are the figures for the Faculty of Arts and Social Sciences, where $52 \%$ of graduates in the 2006-2007 cohort were well-matched in this respect, the 200I-2002 cohort from the Faculty of Psychology and Neuroscience (68\%) and the 2006-2007 cohort from the Faculty of $\operatorname{Law}(60 \%)$. In the case of the Faculty of Arts and Social Sciences, the vast majority of horizontally mismatched graduates indicated that their work required no specific field rather than a completely different field, indicating that the work domain for graduates of that faculty is rather broad and not defined by specific disciplinary requirements.

Table $\mathbf{2 b}$

Vertical match

\begin{tabular}{lcc}
\hline & \% working at university level or higher \\
& 2006-2007 & 2001-2002 \\
\hline Business and Economics & 93 & 84 \\
Health, Medicine and Life Sciences & 83 & 82 \\
Arts and Social Sciences & 90 & $\mathrm{x}$ \\
Psychology and Neuroscience & 90 & 89 \\
Law & 82 & 87 \\
Maastricht University & 86 & 84 \\
\hline
\end{tabular}

$1=$ too little information about the Faculty of Humanities and Sciences $\mathrm{x}=$ too few cases

We also look at the vertical match (i.e. whether graduates are working in a job for which a university degree is required), which like the horizontal match is an important indicator of the quality of the fit between education and the job. Table 2 b shows that $86 \%$ of the respondents who graduated in 2006-2007 and $84 \%$ of the respondents who graduated in 200I-2002 were well-matched vertically in their job at the time of the survey. There is again substantial variation between disciplines, especially in the 2006-2007 cohort. ${ }^{4}$ Graduates (2006-2007 cohort) from Psychology \& Neurosciences, Business \& Economics and Arts \& Social Sciences report excellent vertical matching rates of $90 \%$ or more. In case of Psychology and Neurosciences this also holds for the graduates from the $200 \mathrm{I}-2002$ cohort. This

4. For the Faculty of Health, Medicine and Life Sciences a strong difference is again visible between the Medical Study (99\% of graduates from the 2006-2007 cohort and 100\% of the graduates from the $200 \mathrm{I}-2002$ cohort are matched perfectly in terms of this indicator) and Health and Life Sciences ( $77 \%$ and $73 \%$ respectively). percentage is lower, although still quite high, for graduates from the 2006-2007 cohort of the Law and Health, Medicine and Life Sciences faculties school alumni from the 200I-2002 cohort, of whom only $82-83 \%$ are employed in a university-level job. These outcomes are highly correlated with degree specificity as well as labour market conditions in the particular field. In all disciplines and for both cohorts, the percentage of graduates with an excellent vertical match increased markedly between the first and the current job.

\section{Income and working hours}

At the time of the survey, the median gross income of Maastricht University alumni of 2006-2007 is €3500 per month, and this rises to $€ 4500$ for the cohort of 200I2002 alumni (see Table 3). These numbers closely match the results of previous surveys, although for the younger cohort the median income has dropped slightly, from $€ 3600$ per month to $€ 3500$ per month. Income patterns across disciplines seem to remain more or less stable, both with respect to previous survey years and in terms of career development. Business and Economics and Law graduates consistently show the highest monthly earnings. The differences are only partly accounted for by the higher working hours of these graduates.

Table 3

Income and working hours

\begin{tabular}{lcccc}
\hline & $\begin{array}{c}\text { gross income per month } \\
\text { (median) }\end{array}$ & \multicolumn{2}{c}{$\begin{array}{c}\text { regular working hours } \\
\text { per week }\end{array}$} \\
& $2006-2007$ & $2001-2002$ & $2006-2007$ & 2001-2002 \\
\hline Business and Economics & 4.500 & 6.000 & 40 & 40 \\
Health, Medicine and Life & 3.200 & 4.038 & 36 & 32 \\
Sciences & 2.850 & $\mathrm{x}$ & 39 & $\mathrm{x}$ \\
Arts and Social Sciences & 2.800 & 3.550 & 36 & 33 \\
Psychology and Neuroscience & 3.800 & 4.900 & 40 & 37 \\
Law & 3.500 & 4.500 & 38 & 36 \\
Maastricht University & & & & \\
\hline
\end{tabular}

$1=$ too little information about the Faculty of Humanities and Sciences $\mathrm{x}=$ too few cases

\section{Job satisfaction}

Job satisfaction of Maastricht University graduates is generally high, although it has dropped somewhat compared to last year's survey, especially for the younger cohort. Whereas $79 \%$ of the younger cohort was satisfied with their job last year, this has dropped to $73 \%$ this year. For the older cohort the drop was small, from $84 \%$ to $82 \%$.

5. The relative low median income of Health, Medicine and Life Sciences graduates is strongly influenced by the relatively low median income of graduates from Health and Life Sciences studies. Medical graduates earn substantially more than Health, Medicine and Life Sciences graduates: 3800 compared to 3200 for the $2006-2007$ cohort, and 5200 compared to 3700 for the $200 \mathrm{I}-2002$ cohort. Due to the structure of their career paths, Medical alumni show the biggest income growth between six and eleven years after graduation. 
The trends in the proportion of graduates who find that their current job offers good career opportunities are quite different - almost the opposite in some respects - showing a slight decrease from $65 \%$ to $62 \%$ for the older cohort, and a slight increase from $70 \%$ to $73 \%$ for the younger cohort.

Table 4

Job satisfaction, career opportunities ${ }^{1}$

\begin{tabular}{lcccc}
\hline & \multicolumn{2}{c}{ \% satisfied with job } & \multicolumn{2}{c}{$\begin{array}{c}\text { job offers good career } \\
\text { opportunities }\end{array}$} \\
& $2006-2007$ & $2001-2002$ & $2006-2007$ & $2001-2002$ \\
\hline $\begin{array}{l}\text { Business and Economics } \\
\text { Health, Medicine and Life }\end{array}$ & 73 & 80 & 73 & 73 \\
Sciences & 75 & 83 & 59 & 58 \\
Arts and Social Sciences & 60 & $x$ & 50 & $x$ \\
Psychology and Neuroscience & 83 & 89 & 57 & 46 \\
Law & 69 & 80 & 62 & 63 \\
Maastricht University & 73 & 82 & 73 & 62 \\
\hline
\end{tabular}

$1=$ too little information about the Faculty of Humanities and Sciences

$x=$ too few cases

\section{International orientation of Maastricht University and its graduates}

With its international orientation and the fact that English is the main language of instruction in many study programs, Maastricht University attracts an increasing number of international students for all faculties. It is interesting to see whether this international orientation is extended beyond the time of the study in Maastricht, in the form of high proportions of graduates studying abroad. Table 5 shows the percentage of Maastricht University alumni of the various cohorts who are currently working inside and outside the Netherlands, split by faculty. For Maastricht University as a whole, almost one fifth (19\%) of the alumni of the 20062007 cohort are working in European countries outside the Netherlands, and $4 \%$ are working outside of Europe. These percentages drop somewhat for the older cohort, to $15 \%$ and $3 \%$ respectively. These numbers include foreign students who returned to their home country after graduation.

Table 5

Percentage currently working abroad ${ }^{1}$

\begin{tabular}{lrrrrrr}
\hline & \multicolumn{3}{c}{$2006-2007$} & \multicolumn{3}{c}{$2001-2002$} \\
& NL & EU & 0ther & NL & EU & 0ther \\
\hline Business and Economics & 50 & 44 & 6 & 62 & 34 & 4 \\
Health, Medicine and Life & 91 & 7 & 2 & 91 & 7 & 2 \\
Sciences & & & & & & \\
Arts and Social Sciences & 44 & 52 & 2 & $x$ & $x$ & $x$ \\
$\begin{array}{l}\text { Psychology and } \\
\text { Neuroscience }\end{array}$ & 80 & 20 & 0 & 82 & 18 & 0 \\
Law & 88 & 8 & 5 & 92 & 5 & 3 \\
Maastricht University & 77 & 19 & 4 & 83 & 15 & 3 \\
\hline
\end{tabular}

$1=$ too little information about the Faculty of Humanities and Sciences $\mathrm{x}=$ too few cases
There are large differences between the faculties. ${ }^{6}$ Especially graduates from the School of Business and Economics are internationally active. But the younger cohort of alumni from the Faculty of Arts and Social Sciences show a strikingly high propensity to work abroad. No less than $54 \%$ of these graduates were working in countries other than the Netherlands. Asked to what extent the education received at Maastricht University prepared them for the international labour market, $42 \%$ of the $2006-2007$ cohort and $41 \%$ of the $200 \mathrm{I}-$ 2002 cohort responded that they felt prepared to a high or very high extent. For the younger cohort, this represents a considerable drop compared to last year, from $5 \mathrm{I} \%$ to $42 \%$. There are large differences between faculties, which broadly reflect the differences in the proportions working abroad. The School of Business and Economics and the Faculty of Arts and Social Science are the most internationally oriented, with $77 \%$, respectively $56 \%$, of 2006-2007 graduates feeling prepared for the international labour market.

\section{Satisfaction with study at Maastricht University}

Finally, alumni were asked to reflect on their time at Maastricht University and assess which choices they would make in retrospect. In the 2006-2007 cohort, $75 \%$ of the alumni would again choose exactly the same study at Maastricht University. For the cohort that graduated in the academic year 200I-2002, this proportion was $71 \%$. Table 6 presents the survey results for the three cohorts by faculty. ${ }^{7}$

\section{Table 6}

Percentage of alumni who would again choose to study at Maastricht University ${ }^{1}$

\begin{tabular}{lcc}
\hline & 2006-2007 & 2001-2002 \\
\hline Business and Economics & 88 & 75 \\
Health, Medicine and Life Sciences & 76 & 68 \\
Arts and Social Sciences & 67 & $X$ \\
Psychology and Neuroscience & 76 & 70 \\
Law & 64 & 75 \\
Maastricht University & 75 & 71 \\
\hline
\end{tabular}

$1=$ too little information about the Faculty of Humanities and Sciences $\mathrm{x}=$ too few cases

In line with these findings, $77 \%$ of the respondents report that their study at Maastricht University is still (very) useful for their current job. These results are consistent across faculties and cohorts.

6. In case of the Law Faculty, considerable variation exists also within the Faculty between graduates of Dutch Law (Dutch labour market oriented) and graduates of International Law (European labour market oriented).

7. Within the Faculty of Health, Medicine and Life Sciences, graduates of the Medical studies are significantly more satisfied with their study choice in retrospect. $56-70 \%$ of the graduates of Health and Life Science would again choose the same study at Maastricht University compared to $89-91 \%$ of the Medical graduates. 


\section{Appendix A}

Table 7

Trends in unemployment ${ }^{1}$

\begin{tabular}{|c|c|c|c|c|c|c|c|}
\hline & 2007 & 2008 & 2009 & 2010 & 2011 & 2012 & 2013 \\
\hline & $\mathrm{T}+5$ & $\mathrm{~T}+5$ & $\mathrm{~T}+5$ & $\mathrm{~T}+5$ & $\mathrm{~T}+5$ & $\mathrm{~T}+5$ & $\mathrm{~T}+5$ \\
\hline & $2000-2001$ & $2001-2002$ & $2002-2003$ & 2003-2004 & $2004-2005$ & $2005-2006$ & 2006-2007 \\
\hline Business and Economics & 0,7 & 0,5 & 3,2 & 2,2 & 5,4 & 1,9 & 0,0 \\
\hline Health and Life Sciences & 1,8 & 1,8 & 2,4 & 1,7 & 2,7 & 2,1 & 3,1 \\
\hline Medicine & 1,4 & 1,3 & 0,0 & 0,0 & 1,5 & 0,0 & 0,0 \\
\hline Arts and Social Sciences & - & - & - & - & 3,8 & 10,1 & 5,7 \\
\hline Psychology and Neuroscience & 0,0 & 5,7 & 1,9 & 7,0 & 10,3 & 4,2 & 0,0 \\
\hline Law & 1,0 & 0,0 & 1,2 & 4,3 & 5,0 & 0,0 & 6,8 \\
\hline \multirow[t]{4}{*}{ Maastricht University } & 1,1 & 1,3 & 2,3 & 2,5 & 4,4 & 2,7 & 3,2 \\
\hline & 2007 & 2008 & 2009 & 2010 & 2011 & 2012 & 2013 \\
\hline & $\mathrm{T}+10$ & $\mathrm{~T}+10$ & $\mathrm{~T}+10$ & $\mathrm{~T}+10$ & $\mathrm{~T}+10$ & $\mathrm{~T}+10$ & $\mathrm{~T}+10$ \\
\hline & 1995-1996 & 1996-1997 & 1997-1998 & 1998-1999 & $1999-2000$ & $2000-2001$ & $2001-2002$ \\
\hline Business and Economics & 1,5 & 0,9 & 0,0 & 3,0 & 2,8 & 0,9 & 0,9 \\
\hline Health and Life Sciences & 1,9 & 2,2 & 0,6 & 0,6 & 2,0 & 1,2 & 3,1 \\
\hline Medicine & 1,9 & 2,3 & 0,0 & 0,0 & 2,6 & 1,8 & 0,0 \\
\hline Arts and Social Sciences & - & - & - & - & - & - & - \\
\hline Psychology and Neuroscience & - & - & 0,0 & 0,0 & 0,0 & 3,8 & 0,0 \\
\hline Law & 2,4 & 1,2 & 0,0 & 1,5 & 0,0 & 6,1 & 1,6 \\
\hline Maastricht University & 2,0 & 2,0 & 0,3 & 1,7 & 2,0 & 2,0 & 2,0 \\
\hline
\end{tabular}

$1=$ too little information about the Faculty of Humanities and Sciences

$\mathrm{x}=$ too few cases 


\section{Colofon}

Copyright (C) 20I3, Research Centre for Education and the Labour Market, Maastricht. No part of this publication may be reproduced in any way without prior permission of the Director of ROA.

Research Centre for Education and the Labour Market

P.O. Box 616

6200 MD Maastricht

The Netherlands

secretary-roa-sbe@maastrichtuniversity.nl

www.roa.nl

Maastricht University

School of Business and Economics

\section{Layout}

ROA secretary, Maastricht

\section{October 2013}


Researchcentrum voor Onderwijs en Arbeidsmarkt

Postbus 616

6200 MD Maastricht

$\mathrm{T}+31433883647$

F +31 433884914

secretary-roa-sbe@maastrichtuniversity.nl

www.roa.nl

Maastricht University

School of Business and Economics 